\title{
Heat load increases the risk of clinical mastitis in dairy cattle
}

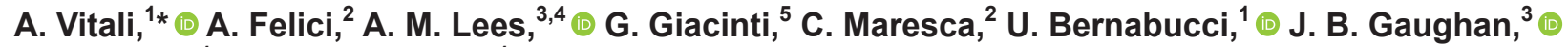 \\ A. Nardone, ${ }^{1} \odot$ and N. Lacetera ${ }^{1}$ \\ ${ }^{1}$ Dipartimento Scienze Agrarie e Forestali, Università della Tuscia, 01100 Viterbo, Italy \\ ${ }^{2}$ Istituto Zooprofilattico Sperimentale dell'Umbria e delle Marche, 06126 Perugia, Italy \\ ${ }^{3}$ School of Agriculture and Food Sciences, The University of Queensland, Gatton, QLD 4343, Australia \\ ${ }^{4}$ School of Environmental and Rural Science, Animal Science, University of New England Australia, Armidale, NSW, Australia, 2350 \\ ${ }^{5}$ Istituto Zooprofilattico Sperimentale del Lazio e Toscana, 00178 Roma, Italy
}

\section{ABSTRACT}

The study was aimed at assessing heat load-related risk of clinical mastitis $(\mathrm{CM})$ in dairy cows. Records of CM for the years 2014 and 2015 were obtained from a large conventional dairy farm milking about 1,200 Holstein cows in central Italy. A case of CM was defined by the presence of clinical signs and veterinary confirmation. Quarter milk samples were collected and bacteriological investigated for each CM. Etiological agents were identified and classified as environmental or contagious pathogens. Hourly weather data from the nearest weather station were used to calculate heat load index (HLI). Upper and lower thresholds of HLI, at which the animal accumulates or dissipates heat, were settled and used to measure heat load balance through the accumulated heat load (AHL) model. Zero and positive values of AHL indicate periods of thermoneutral and heat accumulation, respectively. Each case of CM was associated with HLI-AHL values recorded $5 \mathrm{~d}$ before the event. The risk of $\mathrm{CM}$ was evaluated using a case-crossover design. A conditional logistic regression model was used to calculate the odds ratio and $95 \%$ confidence intervals of $\mathrm{CM}$ recorded in thermo-neutral $(\mathrm{AHL}=0)$ or heat load $(\mathrm{AHL}>0)$ days, pooled or stratified for pathogen type (environmental or contagious). Classes of AHL as low $(<6.5)$, medium (6.6-34.9), and high (>35) were included in the model. Other variables included in the model were milk yield as liters $(<20,20-30$, and $>30)$, days in milk $(<60$, $60-150$, and $>150)$, and parity $(1,2-3$, and $>3)$. A total of 1,086 CM cases were identified from 677 cows. Escherichia coli, Streptococcus spp., and Streptococcus uberis were the environmental pathogens isolated with the highest frequency; Staphylococcus aureus prevailed within contagious species. The analysis of pooled data

Received October 15, 2019.

Accepted April 11, 2020.

*Corresponding author: vitali@unitus.it indicated a significant effect of heat load on the occurrence of $\mathrm{CM}$ in the contagious pathogen stratum. Higher milk yield, middle and late stage of lactation, and older parity increased the risk of CM under heat load conditions. However, the association between pathogen type and these factors was not clear because the model provided significant odds ratios within all pathogen categories. The present study provided the first evidence of an association between HLI and CM in dairy cattle and suggested the ability of the AHL model to assess the risk of mastitis associated with heat load. Key words: heat load index, dairy cattle, clinical mastitis, pathogen type, thermal balance

\section{INTRODUCTION}

The effect of high temperatures on livestock wellbeing is an issue of increasing concern, especially in light of the future scenarios on global warming. Earth's temperature is forecasted to rise in the next decades by $1.5^{\circ} \mathrm{C}$ (IPCC 2018), and prolonged periods of excessively hot weather, as heat waves, are expected to increase in frequency, intensity, and length (Beniston et al., 2007). This climate scenario will be a concern and may have serious negative consequences on animal welfare, health, and production. Heat stress is generated by high temperatures that induce an imbalance between heat production and dissipation capacity of cattle (Das et al., 2016), increasing the risk of production losses (Bernabucci et al., 2014), infections (Olde Riekerink et al., 2007), and mortality (Vitali et al., 2015).

Mastitis (subclinical and clinical) is a multifactorial problem and several factors may contribute to outbreaks. Climate is one of these factors and high values of temperature and humidity may be related to udder infection, occurrence of clinical mastitis (CM), and milk SCC (Morse et al., 1988). Temperature-humidity index (THI), a long-standing bioclimatic index that combines temperature and humidity, is widely used to define the degree of heat stress in livestock. Studies 
have shown an increase in SCC with increased values of THI (Smith et al., 2013; Bertocchi et al., 2014; Bouraoui et al., 2002) and critical thresholds of THI were provided to indicate higher rates of CM (Morse et al., 1988; Zeinhom et al., 2016).

Heat load index (HLI) is a new bioclimatic index that incorporates the effect of ambient temperature (AT), relative humidity $(\mathbf{R H})$, solar radiation $(\mathbf{S R})$, and wind speed (WS). The HLI and related accumulated heat load (AHL) model were developed on beef cattle to estimate the heat load from animals as a function of the time spent above or below specific HLI thresholds in a day (Gaughan et al., 2008). The HLI-AHL model is a bi-dimensional approach that considers the contemporary effect of intensity and length of exposure to heat, compared with a one-dimensional THI model that measures only the intensity of exposure to heat. The HLI was used to assess the effect of heat stress in dairy farming, and data highlighted significant milk yield loss of high producing dairy cattle when exposed at high values of HLI compared with thermo-neutral conditions (Gaughan and Lees, 2010).

To date there have been limited dairy studies using the HLI-AHL models in dairy systems (Tucker et al., 2008; Schütz et al., 2009, 2010, 2014); however, these models have not been used to investigate the association between health outcomes and periods of heat load in dairy cattle. Therefore, the present study investigated the effect of heat load on the occurrence of generic and pathogen type (contagious and environmental)-specific CM throughout the HLI-AHL models in a large conventional Italian dairy farm.

\section{MATERIALS AND METHODS}

\section{Study Design and Farm Management}

The relationship between heat load and CM was evaluated employing a case-crossover design using a time-stratified referent selection approach. In this design, individuals serve as their own control and timeinvariant variables are controlled by design (Maclure and Mittleman, 2000; Jaakkola, 2003; Wilson et al., 2013). Time-stratified referent selection is done so that long-term (e.g., yearly and seasonal) and short-term (e.g., day of week) trends are accounted for, ensuring unbiased conditional logistic regression estimates (Janes et al., 2005). In this analysis, referent days were selected within the same month and calendar year of the event, and on all the same days of week. Up to 4 control days per case were used. For example, if an individual experienced the event on Tuesday, July 14, 2015 (event day), then all other Tuesdays within July
2015 (July 7, 21, and 28) become referent days. The multi events of CM for the same cow were counted as independent events (new cases) if the time between 2 events was at least $2 \mathrm{wk}$, and during the study, none of the multi events were recorded within this washout period.

No evidence indicates a latency period between the exposure to climate challenge and the appearance of clinical signs of mastitis. Our knowledge about heat challenges and milk outcomes (quantity and quality) indicates a latency of 3 to $5 \mathrm{~d}$ (Bernabucci et al., 2014). We are aware that the process of heat-related mastitis infection is different from that affecting production, but at the same time we are confident that a lag time exists between climate challenge and mastitis outcome. Therefore, we have chosen arbitrarily to associate each $\mathrm{CM}$ to the climate condition (HLI-AHL) experienced 5 $\mathrm{d}$ before the event.

Data for CM were recorded for 2 yr (January 2014 to December 2015) in a large conventional Italian dairy farm with 1,050 to 1,200 lactating Holstein cows. The cows were housed all year in freestall barn with a high roof and open on all sides. Cows were milked twice per day, and they were fed after each milking with TMR. Data of cows were extrapolated from test-day records during the studied period and they are reported here as median (interquartile range): 170 (178) for DIM, 28 (13) L/cow per day for milk yield, 3.7 (1) for fat as percentage, 3.3 (0.4) for protein as percentage, and 84,000 $(201,000)$ for SCC.

Mastitis prevention measures adopted by farm were the hygiene of milking parlor for the pre- and post-teat dipping operations. Cows positive for Staph. aureus were milked last, a specific pre- and post-teat dipping dispenser was used, and gloves were discharged after each turn. In addition, 2 times a year the presence of Staph. aureus was monitored and positive cases were immediately separated and moved into the corresponding group.

The climate control measures were represented by cooling equipment (fans and sprinklers) in the holding area for milking parlor, where cows were cooled, on average, $1 \mathrm{~h}$ per day. Finally, each case of CM was associated with cows' information: ID, average daily milk yield (liters) recorded during the week before the event, parity, and DIM at CM detection.

\section{Clinical Mastitis Detection and Bacterial Identification}

Mastitis was defined based on clinical signs first identified by the milker and by subsequent veterinary confirmation. The presence of swelling, heat, hardness, 
redness, or pain, as well as abnormal changes of the milk such as a watery appearance, flakes, clots, or pus, were considered as clinical signs. All animals detected with $\mathrm{CM}$ received medical treatments. The $\mathrm{CM}$ episodes were characterized at the quarter level and the cow was considered as the analytical unit of the study even when more than one quarter was affected at once. This latter case was not frequent (35 cases corresponding to $3.22 \%$ ) and it was mainly related to the same pathogen such as Mycoplasma bovis, Staph. aureus, and Escherichia coli. However, the event of CM was categorized by evaluating cows' clinical history in the few cases (5) when contagious and environmental pathogens were isolated from different quarters. Therefore, if the cow has been previously positive to the same contagious pathogen then the CM was classified as environmental (4 cases). In the other cases, never positive or positive to another contagious pathogen (1 case), CM was categorized as the latest contagious species.

Milk samples from infected quarters were collected in duplicate, placed on ice, and transported to the laboratory, where they were immediately frozen at $-20^{\circ} \mathrm{C}$ until analysis. Bacteriological milk culture was carried out by method recognized by the American National Mastitis Council for bovine mastitis (NMC, 1999) and only one of each pair of duplicate quarter samples was routinely selected for microbial culture. The second paired sample was kept frozen and cultured only in cases where the first sample was contaminated or negative.

Samples to be cultured were thawed to room temperature and $0.01 \mathrm{~mL}$ of each sample was spread on blood agar plates (5\% defibrinated sheep blood). Inoculated plates were incubated at $37^{\circ} \mathrm{C}$ and examined after 24 and $48 \mathrm{~h}$ for bacterial growth.

Colonies were provisionally identified based on size, Gram stain, morphology, and hemolysis pattern. Representative colonies were then subcultured on blood agar plates and incubated again at $37^{\circ} \mathrm{C}$ for $24 \mathrm{~h}$ to obtain pure cultures. Gram-positive cocci found negative to catalase reaction test were identified as streptococci and species were confirmed by the API Strep identification system (bioMerieux, Marcy l'Etoile, France). Coagulase tube test was used to differentiate catalasepositive, gram-positive cocci as Staph. aureus or CNS.

Further characterization of gram-negative organisms involved motility testing, oxidase test, and then testing with the API20E system or API20NE (bioMerieux). Organisms that could not be identified by the API system were reported as "other gram negatives." Finally, no bacterial pathogens such as yeast, fungi, or algae were identified by the API 20AUX (bioMerieux).
If 3 or more pathogens were present, the milk sample was considered contaminated and the duplicate was then cultured. If the duplicate sample also yielded 3 or more bacterial pathogens, the quarter sample was classified as contaminated. If no growth was observed in a single sample, the duplicate sample was cultured (bioMerieux). If the duplicate sample did not show growth, the quarter sample was classified as negative.

The main pathogens were classified as contagious $(\mathbf{C}$; Fox and Gay, 1993) or environmental (E; Smith et al., 1985). The Pasteurella spp. was classified as C (Swartz and Petersson-Wolfe, 2016). The Prototheca zopfii, although classified as E (Ely et al., 2019), sometimes may have $\mathrm{C}$ behavior. In this study, Prototheca was identified only through morphology and phenotypic methods, and due to the low prevalence detected during the trial, we classified Prototheca zopfii as E pathogens. The bacteria Streptococcus dysgalactiae, which may be considered as both C and E (Lundberg et al., 2014), was classified as both $\mathrm{C}$ and $\mathrm{E}$ and was excluded or considered alternatively within contagious and environmental types that were classified in this case as $\mathbf{C}^{+}$and $\mathbf{E}^{+}$, respectively. Finally, the CNS emerging pathogens of mastitis are difficult to classify as either strictly C or E pathogens (Pyörälä and Taponen, 2009), and thus they were classified as neither and these cases of CM were classified in a separate category $(\mathbf{N})$. However, the effect of heat stress within pathogen type $\mathrm{N}$ on the occurrence of CM was evaluated.

\section{Heat Load Index}

Weather data of $\mathrm{AT}\left({ }^{\circ} \mathrm{C}\right), \mathrm{RH}(\%)$, SR $\left(\mathrm{W} / \mathrm{m}^{2}\right)$, and WS $(\mathrm{m} / \mathrm{s})$ were used to calculate the HLI. They were measured hourly at $3 \mathrm{~m}$ above the ground from the nearest weather station located $6 \mathrm{~km}$ far the farm and belonging to the institutional meteorological network of the Lazio region. Farm and weather station are located in the same topological zone that corresponds to the flat area (0-10 $\mathrm{m}$ above sea level) northwest of Rome. The HLI is based on a black globe (BG) temperature threshold of $25^{\circ} \mathrm{C}$ and it was calculated as described in detail in Gaughan et al. (2008).

First, the BG temperature was calculated starting from AT and SR by using Equation 1.

$$
\mathrm{BG}=1.33 \times \mathrm{AT}-2.65 \times \mathrm{AT}^{0.5}+3.21 \times \log _{10}(\mathrm{SR}+1)+3.5 .
$$

Then, the HLI was calculated with nonlinear equation model when BG temperature was above $25^{\circ} \mathrm{C}$ or with a 
linear model if $\mathrm{BG}$ temperature was below $25^{\circ} \mathrm{C}$ (Equation 2).

$$
\begin{aligned}
& \mathrm{HLI}= \\
& \left\{\begin{array}{l}
8.62+(0.38 \times \mathrm{RH})+(1.55 \times \mathrm{BG})-(0.5 \times \mathrm{WS})+\mathrm{e}^{(2.4-\mathrm{WS})}, \\
\text { if } \mathrm{BG} \geq 25^{\circ} \mathrm{C} \\
10.66+(0.28 \times \mathrm{RH})+(1.3 \times \mathrm{BG})-\mathrm{WS}, \\
\text { if } \mathrm{BG}<25^{\circ} \mathrm{C}
\end{array}\right.
\end{aligned}
$$

The term e is the base of the natural logarithm (approximate value of $\mathrm{e}=2.71828$ ).

The AHL model was used to measure the animal's heat load balance that is determined by the duration of exposure above or below specific thresholds of HLI. Two HLI thresholds were established: (1) an HLI of 82 was defined as the upper threshold (UT) above which the animal accumulates heat, and (2) an HLI of 79 was defined as the lower threshold (LT) below which the animal dissipates heat, typically occurring at nighttime.

The LT and UT described by Gaughan et al. (2008) were initially defined for feedlot cattle. However, due to the metabolic differences between growth and lactation, these thresholds were modified for dairy cattle. Therefore, the UT was decreased from 86 to 82 units of HLI; this adjustment was done in an attempt to account for the metabolic heat load associated with milk synthesis and differences in diets (i.e., those containing higher grain to forage ratios as observed in feedlot rations). Furthermore, as thermal exchanges are influenced by biological factors such as tissue insulation (i.e., subcutaneous fat deposits), particularly under the skin (Hahn, 1985), the LT was increased from an HLI of 77 to 79 .

The AHL model was used to measure the animal's heat load balance that is determined by the duration of exposure above UT or below LT. Equation 3 describes the relationship between HLI and AHL per point in time.

$$
\mathrm{AHL}=\left\{\begin{array}{c}
\frac{\mathrm{HLI}_{\mathrm{ACC}}-\mathrm{HLI}_{\mathrm{LT}}}{0.5}, \text { if } \mathrm{HLI}_{\mathrm{ACC}}<\mathrm{HLI}_{\mathrm{LT}} \\
\mathrm{M} \mathrm{HLI}_{\mathrm{UT}} \\
0, \text { if } \mathrm{HLI}_{\mathrm{LT}} \leq \mathrm{HLI}_{\mathrm{ACC}} \leq \mathrm{HLI}_{\mathrm{ACC}}>\mathrm{HLI}_{\mathrm{UT}}, \quad[3]
\end{array}\right.
$$

where $\mathrm{HLI}_{\mathrm{ACC}}=$ the actual HLI value at a point in time, $\mathrm{HLI}_{\mathrm{LT}}=$ the HLI lower threshold where cattle will dissipate heat (for this study 79), $\mathrm{HLI}_{\mathrm{UT}}=$ the HLI upper threshold where cattle will gain heat (for this study 82 ), and $\mathrm{M}=$ the number of measures per hour [i.e., number of times HLI data are collected per hour (for this study $\mathrm{M}=1$ )] as adapted from Gaughan et al. (2008).

Whether HLI is greater of the $\mathrm{HLI}_{\mathrm{UT}}$, the AHL model assumes a positive value (condition 2 of Equation 3), which means that the animal has accumulated some heat from its environment; in this study it corresponds to the heat accumulated during the latest hour. At the next point in time (the next hour in this case), the AHL may decrease if HLI is below the $\mathrm{HLI}_{\mathrm{LT}}$ (condition 1 of Equation 3), may increase if HLI is still above HLI $\mathrm{UT}_{\mathrm{UT}}$ (condition 2 of Equation 3), or may be unvaried if HLI is between the 2 thresholds (condition 3 of Equation 3). We imposed that AHL does not fall below zero, as an AHL value of 0 indicates that the animal is in a state of thermal balance where the animal does not have any AHL to dissipate (Gaughan et al., 2008). Then, daily average values of AHL were calculated from hourly values of AHL. Finally, we considered values of AHL $>0$ as the heat stress condition for the cow.

\section{Statistical Analyses}

Odds ratios and 95\% confidence intervals were estimated using conditional logistic regression, conditioning on cows. Daily average AHL was examined as a categorical variable, at first in a binary way $(0$ and $>0)$, where a day with AHL $>0$ was considered as a heat stress condition during which cows were anticipated to gain heat, whereas a day with values of $\mathrm{AHL}=0$ was considered as a thermo-neutral condition. Moreover, with the purpose of further investigating the effect of AHL, we created 4 classes: the first one is the zero-class $(\mathrm{AHL}=0)$, whereas the other 3 classes were defined based on the quantile method (equal number of cases in each class), then the following classes were defined: (1) $0<\mathrm{AHL} \leq 6.5$; (2) $6.5<\mathrm{AHL} \leq 35$; and (3) AHL $>35$. Models were fitted for the exposure to AHL assigned to the fifth day before the event (lag $5 \mathrm{~d}$ ). Stratified CM events and their corresponding controls by pathogen type, average daily milk yield during the week before the event $(<20,20-30$, and $>30$ as liters $)$, DIM $(60,60-150$, and $>150$ as DIM), and parity (1, $2-3$, and $>3$ as calving) at CM detection, were evaluated. Statistical significance was evaluated by z-test and set at $P<0.05$. The analysis was performed using Stata software 11.2 (release 11, 2009, StataCorp, College Station, TX).

\section{RESULTS}

The monthly patterns of HLI, AHL, and CM recorded during the $2 \mathrm{yr}$ are shown in Figure 1. The 
Table 1. Absolute and relative frequency (\% of the total) of pathogen species identified in milk samples collected from dairy cattle with signs of clinical mastitis ${ }^{1}$

\begin{tabular}{|c|c|c|c|c|}
\hline \multirow[b]{2}{*}{ Pathogen species } & \multirow{2}{*}{$\begin{array}{l}\text { Pathogen } \\
\text { type }^{2}\end{array}$} & \multicolumn{2}{|c|}{ Frequency } & \multirow[b]{2}{*}{ Reference } \\
\hline & & No. & $\%$ & \\
\hline Escherichia coli & $\mathrm{E}$ & 354 & 32.6 & Smith et al., 1985 \\
\hline Serratia marcescens & $\mathrm{E}$ & 40 & 3.7 & Smith et al., 1985 \\
\hline Klebsiella spp. & $\mathrm{E}$ & 6 & 0.6 & Smith et al., 1985 \\
\hline Streptococcus spp. & $\mathrm{E}$ & 127 & 11.7 & Smith et al., 1985 \\
\hline Streptococcus uberis & $\mathrm{E}$ & 109 & 10.0 & Smith et al., 1985 \\
\hline Streptococcus dysgalactiae & $\mathrm{E}-\mathrm{C}$ & 83 & 7.6 & Lundberg et al., 2014 \\
\hline Enterococcus spp. & $\mathrm{E}$ & 15 & 1.4 & Smith et al., 1985 \\
\hline Staphylococcus aureus & $\mathrm{C}$ & 136 & 12.5 & Fox and Gay, 1993 \\
\hline CNS & $\mathrm{N}$ & 84 & 7.7 & Pyörälä and Taponen, 2009 \\
\hline Mycoplasma bovis & $\mathrm{C}$ & 41 & 3.8 & Fox and Gay, 1993 \\
\hline Pasteurella spp. & $\mathrm{C}$ & 36 & 3.3 & Swartz and Petersson-Wolfe, 2016 \\
\hline Prototheca zopfii & $\mathrm{E}$ & 33 & 3.0 & Ely et al., 2019 \\
\hline Corynebacterium spp. & $\mathrm{C}$ & 22 & 2.0 & Fox and Gay, 1993 \\
\hline
\end{tabular}

${ }^{1}$ Data refer to an Italian large conventional dairy cattle farm and years 2014 and 2015.

${ }^{2}$ The pathogens were classified as indicated by references as environmental (E), contagious $(\mathrm{C})$, both environmental and contagious (E-C), or neither $(\mathrm{N})$.

analysis showed that the highest average value of HLI (79.5 units) and AHL (66 units) occurred in July. The other summer months of June and August had lower values of both HLI and AHL. Positive values of AHL were also recorded in May, September, and October.

Pooled CM were higher in colder months of November, December, and January, and in the hottest month of July, whereas they were lower in August, September, and October.

The identified etiological agents causing mastitis, their classification as pathogen types, and the frequency of occurrence are reported in Table 1. Escherichia coli was the agent with the highest frequency between

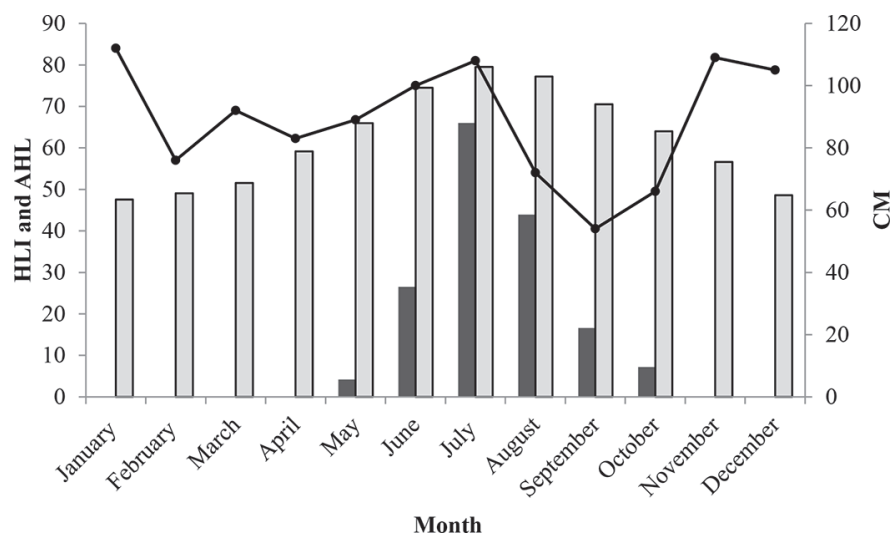

Figure 1. Heat load index (HLI) and accumulated heat load (AHL) on the main axis are averages of the daily values per month. Clinical mastitis (CM) on the secondary axis is the sum of counts per calendar month. Gray bars indicate HLI. Black bars indicate AHL. The solid line indicates pooled cases of CM recorded during the years 2014 and 2015 . all species and within E type. Streptococcus spp. and Streptococcus uberis were the other pathogens more frequent within E type. Staphylococcus aureus was the second agent more frequent considering all species and the most frequent within the $\mathrm{C}$ type.

The logistic regression highlighted a risk of development of CM under heat stress conditions. The analysis provided a pooled odds ratio of $1.358(P=0.007$; CI: 1.086-1.698) indicating a significantly higher risk of CM when cows were exposed to heat load (AHL > 0 ) compared with thermo-neutral conditions $(\mathrm{AHL}=$ $0)$. The effect of AHL $>0$ on the occurrence of CM, within pathogen species considered independently and including CNS classified as the N category, was not significant (Table 2).

Table 3 shows the effects of AHL $>0$ within pathogen type $(\mathrm{C}$ or $\mathrm{E})$ on the occurrence of $\mathrm{CM}$. The model provided the highest odds ratio for the $\mathrm{C}$ pathogens, which was significant $(P=0.005)$ even when $S$. dysgalactiae $\left(\mathrm{C}^{+}\right)$was considered within the $\mathrm{C}$ type $(P=$ 0.004). The odds of $\mathrm{E}$ type were not significant for both $\mathrm{E}(P=0.116)$ and $\mathrm{E}^{+}(P=0.071)$.

Table 4 shows the effects of AHL $>0$ within pathogen type (C or E), stratified for milk yield, DIM, and parity. The model pointed out a significant risk of CM corresponding to a higher class of milk yield $(>30 \mathrm{~L}$ per day) within pathogens $\mathrm{E}(P=0.019), \mathrm{E}^{+}(P=0.010)$, and $\mathrm{C}^{+}(P=0.035)$ and the exception of the $\mathrm{C}$ type $(P=0.069)$.

When DIM was considered, the model provided a significant effect of middle class (60-150 DIM) within environmental pathogens, both $\mathrm{E}(P=0.005)$ and $\mathrm{E}^{+}$ $(P=0.001)$, and an effect of late class $(>150$ DIM $)$ within $\mathrm{C}$ pathogens $(P=0.028)$. 
Table 2. Odds ratio with $95 \%$ CI referring to the risk of developing clinical mastitis (CM) after (5 d) the exposure to the heat stress condition as positive values of the accumulated heat load (AHL $>0$ ) versus CM after $(5 \mathrm{~d})$ the exposure to the climate condition of thermal equilibrium $(\mathrm{AHL}=0)$ stratified by main pathogen species identified

\begin{tabular}{llccc}
\hline Pathogen species & $\begin{array}{l}\text { Pathogen } \\
\text { type }^{1}\end{array}$ & $\begin{array}{l}\text { Odds } \\
\text { ratio }\end{array}$ & P-value & $95 \%$ CI \\
\hline Escherichia coli & $\mathrm{E}$ & 1.280 & 0.214 & $0.867-1.889$ \\
Streptococcus uberis & $\mathrm{E}$ & 0.891 & 0.722 & $0.472-1.680$ \\
Streptococcus spp. & $\mathrm{E}$ & 1.120 & 0.730 & $0.589-2.130$ \\
Streptococcus uberis and spp. & $\mathrm{E}$ & 0.997 & 0.991 & $0.635-1.567$ \\
Prototheca zopfii & $\mathrm{E}$ & 0.928 & 0.915 & $0.234-3.676$ \\
Staphylococcus aureus & $\mathrm{C}$ & 1.837 & 0.071 & $0.948-3.560$ \\
Streptococcus dysgalactiae & $\mathrm{E}-\mathrm{C}$ & 1.477 & 0.333 & $0.670-3.253$ \\
CNS & $\mathrm{N}$ & 0.775 & 0.557 & $0.330-1.817$ \\
\hline
\end{tabular}

${ }^{1}$ The pathogens were classified as environmental (E), contagious $(\mathrm{C})$, both environmental and contagious (E$\mathrm{C})$, or neither $(\mathrm{N})$.

On the other hand, the inclusion of parity indicated a significant effect of parity 2 and 3 within contagious types, both $\mathrm{C}(P=0.002)$ and $\mathrm{C}^{+}(P=0.006)$, and an effect of older cows (parity $>3$ ) within environmental pathogens, both $\mathrm{E}(P=0.041)$ and $\mathrm{E}^{+}(P=0.021)$.

Finally, Table 5 shows the risk of CM within pathogen type (C or E) and stratified for classes of AHL. Compared with thermo-neutral conditions $(\mathrm{AHL}=0)$, a lower class of AHL showed a significant risk within contagious types $\mathrm{C}(P=0.007)$ and $\mathrm{C}^{+}(P=0.005)$, and to a lesser extent, within environmental type $\mathrm{E}^{+}$ $(P=0.034)$. The medium class of AHL pointed out a significant effect within contagious pathogens $\mathrm{C}(P$ $=0.018)$ and $\mathrm{C}^{+}(P=0.024)$. On the other hand, the higher class of AHL did not indicate any effect within pathogen type (C or $\mathrm{E})$.

\section{DISCUSSION}

Monthly patterns of HLI and AHL indicated that cows may be challenged by heat stress from May until October, and in this period, July had the hottest con-

Table 3. Odds ratio with $95 \%$ CI referring to the risk of developing clinical mastitis $(\mathrm{CM})$ after $(5 \mathrm{~d})$ exposure to the heat stress condition as positive values of the accumulated heat load (AHL >0) versus $\mathrm{CM}$ after ( $5 \mathrm{~d}$ ) exposure to the climate condition of thermal equilibrium $(\mathrm{AHL}=0)$ stratified by pathogen type

\begin{tabular}{llll}
\hline $\begin{array}{l}\text { Pathogen } \\
\text { type }^{1}\end{array}$ & $\begin{array}{l}\text { Odds } \\
\text { ratio }\end{array}$ & $P$-value & \multicolumn{1}{c}{$95 \% \mathrm{CI}$} \\
\hline $\mathrm{E}$ & 1.25 & 0.116 & $0.947-1.65$ \\
$\mathrm{C}$ & $2.074^{*}$ & $0.005^{*}$ & $1.247-3.451^{*}$ \\
$\mathrm{E}^{+}$ & 1.273 & 0.071 & $0.98-1.654$ \\
$\mathrm{C}^{+}$ & $1.882^{*}$ & $0.004^{*}$ & $1.228-2.884^{*}$ \\
\hline
\end{tabular}

${ }^{1} \mathrm{E}$ as environmental type excluding Streptococcus dysgalactiae, $\mathrm{C}$ as contagious type excluding $S$. dysgalactiae, $\mathrm{E}^{+}$as environmental type including $S$. dysgalactiae, $\mathrm{C}^{+}$as contagious type including $S$. dysgalactiae.

*Significant value $(P<0.05)$. ditions. This pattern confirms the increased length of heat-related health risks for dairy cows in Italy that have previously been observed in studies investigating heat wave-related mortalities (Vitali et al., 2015).

The HLI-AHL models were used here for the first time to investigate the effect of heat load on the occurrence of CM in dairy cows. The HLI provide a unit value that accounts for $A T, R H, W S, S R$, and $B G$ temperature and then allows the AHL to incorporate both the intensity and duration of exposure to heat stress. The WS and SR are climatic variables needed to characterize outdoor climate conditions. Our animals were confined in high and open (on all sides) barns; then they were exposed, beyond AT and RH, even to natural ventilation and indirect radiation. For this, we are confident that the HLI well represents the microclimate conditions to which the cows were exposed.

Although the farm used fans and sprinklers to cool cows in the holding area before milking, we are confident that $1 \mathrm{~h} / \mathrm{d}$ of cooling was not enough long to cool cows efficiently. Effective cooling should be longer, at least 5 treatments per day of $30 \mathrm{~min}$ each, with $30 \mathrm{~s}$ of wetting and $4.5 \mathrm{~min}$ of forced ventilation, distributed during the day and performed both in the waiting area and feeding alley (Flamenbaum et al., 1986). However, although studies on fan and sprinkler cooling systems where SCC was measured have not indicated increases in mastitis for cooled cows (Bucklin et al., 1991), more research is needed to examine this aspect of cooling as potential confounding effect; in particular, if the water applied does not drain well and the environment remains wet, cows could have an increased likelihood of mastitis.

We have chosen to use the HLI-AHL recorded $5 \mathrm{~d}$ after the event, and the model provided a significant risk of CM corresponding to positive values of AHL. Although arbitrary, this approach was supported, at least in part, by the awareness of a latency period 
Table 4. Odds ratio with 95\% CI referring to the risk of developing clinical mastitis $(\mathrm{CM})$ after $(5 \mathrm{~d})$ exposure to the heat stress condition as positive values of the accumulated heat load (AHL > 0) versus CM after ( $5 \mathrm{~d}$ ) exposure to the climate condition of thermal equilibrium $(\mathrm{AHL}=0)$ stratified by pathogen type, milk yield, DIM, and parity

\begin{tabular}{|c|c|c|c|c|}
\hline $\begin{array}{l}\text { Pathogen } \\
\text { type }^{1}\end{array}$ & Item & $\begin{array}{l}\text { Odds } \\
\text { ratio }\end{array}$ & $P$-value & $95 \%$ CI \\
\hline & Milk yield (L) & & & \\
\hline $\mathrm{E}$ & $<20$ & 1.705 & 0.167 & $0.800-3.637$ \\
\hline $\mathrm{C}$ & $<20$ & 2.285 & 0.239 & $0.578-9.033$ \\
\hline $\mathrm{E}^{+}$ & $<20$ & 1.720 & 0.105 & $0.893-3.313$ \\
\hline $\mathrm{C}^{+}$ & $<20$ & 1.998 & 0.147 & $0.784-5.091$ \\
\hline $\mathrm{E}$ & $20-30$ & 0.829 & 0.400 & $0.535-1.283$ \\
\hline $\mathrm{C}$ & $20-30$ & 2.186 & 0.073 & $0.930-5.136$ \\
\hline $\mathrm{E}^{+}$ & $20-30$ & 0.834 & 0.390 & $0.551-1.261$ \\
\hline $\mathrm{C}^{+}$ & $20-30$ & 1.669 & 0.154 & $0.825-3.380$ \\
\hline $\mathrm{E}$ & $>30$ & $1.647^{*}$ & $0.019^{*}$ & $1.087-2.494^{*}$ \\
\hline $\mathrm{C}$ & $>30$ & 1.945 & 0.069 & $0.950-3.983$ \\
\hline $\mathrm{E}^{+}$ & $>30$ & $1.690^{*}$ & $0.010^{*}$ & $1.131-2.524^{*}$ \\
\hline \multirow[t]{2}{*}{$\mathrm{C}^{+}$} & $>30$ & $2.022^{*}$ & $0.035^{*}$ & $1.050-3.895^{*}$ \\
\hline & DIM & & & \\
\hline $\mathrm{E}$ & $<60$ & 0.953 & 0.854 & $0.568-1.597$ \\
\hline $\mathrm{C}$ & $<60$ & 1.056 & 0.090 & $0.883-5.639$ \\
\hline $\mathrm{E}^{+}$ & $<60$ & 1.003 & 0.990 & $0.603-1.669$ \\
\hline $\mathrm{C}^{+}$ & $<60$ & 2.448 & 0.053 & $0.990-6.055$ \\
\hline $\mathrm{E}$ & $60-150$ & $1.977^{*}$ & $0.005^{*}$ & $1.229-3.179^{*}$ \\
\hline $\mathrm{C}$ & $60-150$ & 1.491 & 0.347 & $0.649-3.426$ \\
\hline $\mathrm{E}^{+}$ & $60-150$ & $2.086^{*}$ & $0.001 *$ & $1.325-3.285^{*}$ \\
\hline $\mathrm{C}^{+}$ & $60-150$ & 1.836 & 0.103 & $0.884-3.814$ \\
\hline $\mathrm{E}$ & $>150$ & 1 & 1 & $0.631-1.584$ \\
\hline $\mathrm{C}$ & $>150$ & $2.812^{*}$ & $0.028^{*}$ & $1.119-7.065^{*}$ \\
\hline $\mathrm{E}^{+}$ & $>150$ & 0.973 & 0.898 & $0.641-1.477$ \\
\hline \multirow[t]{2}{*}{$\mathrm{C}^{+}$} & $>150$ & 1.667 & 0.121 & $0.873-3.183$ \\
\hline & Parity & & & \\
\hline $\mathrm{E}$ & 1 & 1.080 & 0.756 & $0.664-1.755$ \\
\hline $\mathrm{C}$ & 1 & 0.891 & 0.840 & $0.290-2.737$ \\
\hline $\mathrm{E}^{+}$ & 1 & 1.157 & 0.527 & $0.737-1.815$ \\
\hline $\mathrm{C}^{+}$ & 1 & 1.228 & 0.629 & $0.534-2.825$ \\
\hline $\mathrm{E}$ & $2-3$ & 1.185 & 0.377 & $0.813-1.727$ \\
\hline $\mathrm{C}$ & $2-3$ & $2.779^{*}$ & $0.002^{*}$ & $1.446-5.339^{*}$ \\
\hline $\mathrm{E}^{+}$ & $2-3$ & 1.163 & 0.408 & $0.814-1.661$ \\
\hline $\mathrm{C}^{+}$ & $2-3$ & $2.167^{*}$ & $0.006^{*}$ & $1.245-3.773^{*}$ \\
\hline $\mathrm{E}$ & $>3$ & $2.259^{*}$ & $0.041^{*}$ & $1.033-4.941^{*}$ \\
\hline $\mathrm{C}$ & $>3$ & 1.796 & 0.373 & $0.495-6.517$ \\
\hline $\mathrm{E}^{+}$ & $>3$ & $2.410^{*}$ & $0.021^{*}$ & $1.143-5.079^{*}$ \\
\hline $\mathrm{C}^{+}$ & $>3$ & 2.200 & 0.173 & $0.707-6.847$ \\
\hline
\end{tabular}

${ }^{1} \mathrm{E}$ as environmental type excluding Streptococcus dysgalactiae, $\mathrm{C}$ as contagious type excluding $S$. dysgalactiae, $\mathrm{E}^{+}$as environmental type including $S$. dysgalactiae, $\mathrm{C}^{+}$as contagious type including $S$. dysgalactiae.

*Significant value $(P<0.05)$.

between climate challenges and cow outcomes. In our previous study, we found a lag time of 3 to $5 \mathrm{~d}$ between the exposure to high THI and milk loss in dairy cattle (Bernabucci et al., 2014). However, the effect of heat stress on mastitis may be different from that related to productive parameters; therefore, further investigations on different lag times may help to clarify the latency between heat challenge and occurrence of CM.

Figure 1 showed a monthly pattern of $\mathrm{CM}$ and pointed out, under similar climatic conditions, a higher number of events in the early summer compared with late summer. The monthly analysis was not an objec- tive of our study; however, we believe that the summer pattern of CM highlighted here is deserving of reflection. Our previous findings indicated a higher risk of heat-related mortality in dairy cattle at the beginning of summer and lower at the end of the season corresponding to similar levels of heat stress (Vitali et al., 2015). This kind of pattern is called a harvesting effect and it was first observed in heat-related human mortality (Hajat et al., 2002). In other words, early heat challenges affect individuals whose health was already so compromised that they probably would have died in the short term anyway. Further studies need to clarify if the heat-related CM in dairy cattle may be affected by harvesting mechanism or if there is a certain capacity to cope with heat stress throughout the warm season due to the adaptation of cows to hot conditions, the optimization of farm management to mitigate the negative effects of heat stress, or both.

The HLI-AHL models provide an estimation of a cows' heat balance while considering the effect of duration $\times$ intensity through periods of heat load (Gaughan et al., 2008, 2010). Although further studies are needed to definitely establish the upper and lower HLI thresholds for lactating cows, previous studies have characterized decreased milk production in lactating cows associated with increasing HLI (Gaughan and Lees, 2010). The authors described that cows producing $>30 \mathrm{~kg} / \mathrm{d}$ exhibited greater production losses when compared with cows producing $<30 \mathrm{~kg} / \mathrm{d}$ (Gaughan and Lees, 2010). The results presented here suggest that the HLI-AHL models were able to establish an association between heat gained by cows with a greater risk of developing CM. However, the HLI thresholds for dairy cattle need to be validated to completely establish the relationship that exists between CM and HLI-AHL.

Other studies pointed out a role of heat stress on CM outbreaks. Research conducted in Egypt reported an increase of SCC, total cell count, fecal cell count, and $E$. coli count when THI changed from THI $<72$ to THI $>78$ (Zeinhom et al., 2016). In addition, the isolation rate in the milk of both Staph. aureus and E. coli started to increase significantly in milk of cows exposed to values of THI greater than 72 .

A study conducted in Florida investigated the relationship between the incidence rate of $\mathrm{CM}$ and THI (Morse et al., 1988). Those authors studied the pattern of $\mathrm{CM}$ recorded for $6.5 \mathrm{yr}$ from a large north Florida dairy farm (1,050 to 1,350 cows milked/d) and they reported a higher rate of CM corresponding to higher values of daily maximum THI. When maximum THI was $<60$ the signs of $\mathrm{CM}$ were expected in $<2$ cows/1,000 cow-days, whereas 3 or more cows $/ 1,000$ cows per day were expected to display new signs of $\mathrm{CM}$ at maximum daily THI $>78$. A direct comparison between Florida 
and our climatic thresholds is not easy because of different climatic index adopted in the 2 studies. However, the weather data (AT and $\mathrm{RH}$ ) defining our UT of HLI would range between 72 and 80 units if converted into the THI adopted by Morse et al. (1987). In other words, both studies seem to define similar climatic conditions for the beginning of heat-related risk of CM in Holstein dairy cows.

When we considered pathogen type, the model has indicated a significant risk of developing contagious mastitis under heat stress whereas no effect was highlighted for environmental mastitis. Contagious infection results in a typically subclinical, chronic inflammation, with periodic flare-ups of clinical symptoms. The effect of heat stress on cows' susceptibility to infections may help to explain the higher risk of contagious mastitis in the summer. The effect of heat stress on the immune function of dairy cow was investigated and it was associated with depressed cellular immunity (Lacetera et al., 2005). In addition to this, peripheral blood mononuclear cells, isolated from dairy cows and incubated at high AT, showed a decrease in DNA synthesis and an increase in heat-shock proteins, indicating a depressed response of cellular-mediated immunity in heat-shocked cells (Lacetera et al., 2006). Finally, Lecchi et al. (2016) demonstrated that incubation of neutrophils under high AT impaired their functionality with a potential negative effect on the protection of mammary gland against infections.

However, the higher value of somatic cells and the presence of Staph. aureus suggest the presence of chronic subclinical infections; therefore, repeated cases of $\mathrm{CM}$ from the same cow may not be independent of each other. We did not include cluster variables to the conditional logistic regression model and this might affect the results toward higher effects of AHL $>0$ on the occurrence of contagious CM.

A consideration must be made for CNS pathogens that we did not include in the overall analysis because it is difficult to classify them as contagious or environmental (Pyörälä and Taponen, 2009). The analysis did not highlight the effect of heat load within this specific type of pathogens when they were considered alone. However, CNS, recently reclassified as NAS (non-aureus staphylococci), are an emerging issue as the most isolated pathogens in subclinical mastitis worldwide (Condas et al., 2017; Nyman et al., 2017; Valckenier et al., 2019). Improvement for their classification as $\mathrm{C}$ or E will help to account for CNS contribution to heat load-related mastitis within pathogen type.

We also included in the analysis milk yield, DIM, and parity. The risk of CM under heat load was higher, corresponding to higher production level, late lactation stage, and in older cows. The model has not clearly clarified the role of the type of pathogen, indicating in some cases a greater risk for contagious and in others for environmental.

To date no studies have investigated the importance of milk yield, stage of lactation, or parity on the occurrence of $\mathrm{CM}$ under heat stress conditions. However, in general terms higher milk yield and early stage of lactation seems to affect CM (Smith et al., 1985; Hogan et al., 1989), whereas the contribution of age has not been clarified. Olde Riekerink et al. (2007) reported greater incidence of CM in older animals. On the other hand, parity was not significant in the model investigated by

Table 5. Odds ratio with $95 \%$ CI referring to the risk of developing clinical mastitis (CM) after (5 d) exposure to the heat stress condition as positive values of the accumulated heat load (AHL > 0$)$ versus CM after $(5 \mathrm{~d})$ exposure to the climate condition of thermal equilibrium $(\mathrm{AHL}=0)$ stratified by pathogen type $^{1}$

\begin{tabular}{lcccc}
\hline $\begin{array}{l}\text { Pathogen } \\
\text { type }\end{array}$ & $\begin{array}{c}\text { AHL class } \\
\text { (referent =0) }\end{array}$ & Odds ratio & $P$-value & \multicolumn{1}{c}{$95 \%$ CI } \\
\hline $\mathrm{E}$ & 1 & 1.316 & 0.057 & $0.991-1.746$ \\
$\mathrm{C}$ & 1 & $2.043^{*}$ & $0.007^{*}$ & $1.21-3.449^{*}$ \\
$\mathrm{E}^{+}$ & 1 & $1.334^{*}$ & $0.034^{*}$ & $1.022-1.742^{*}$ \\
$\mathrm{C}^{+}$ & 1 & $1.862^{*}$ & $0.005^{*}$ & $1.202-2.886^{*}$ \\
$\mathrm{E}$ & 2 & 0.956 & 0.837 & $0.624-1.465$ \\
$\mathrm{C}$ & 2 & $2.237^{*}$ & $0.018^{*}$ & $1.146-4.366^{*}$ \\
$\mathrm{E}^{+}$ & 2 & 0.982 & 0.93 & $0.652-1.48$ \\
$\mathrm{C}^{+}$ & 2 & $1.996^{*}$ & $0.024^{*}$ & $1.098-3.629^{*}$ \\
$\mathrm{E}$ & 3 & 1.208 & 0.466 & $0.727-2.006$ \\
$\mathrm{C}$ & 3 & 1.481 & 0.362 & $0.636-3.451$ \\
$\mathrm{E}^{+}$ & 3 & 1.237 & 0.391 & $0.761-2.011$ \\
$\mathrm{C}^{+}$ & 3 & 1.516 & 0.274 & $0.72-3.194$ \\
\hline
\end{tabular}

${ }^{1}$ The classes of AHL were based on a quantile method that considers an equal number of cases in each class: (1) as $0<\mathrm{AHL} \leq 6.5,(2)$ as $6.5<\mathrm{AHL} \leq 35$, and $(3)$ as $\mathrm{AHL}>35$.

${ }^{2} \mathrm{E}$ as environmental type excluding Streptococcus dysgalactiae, C as contagious type excluding $S$. dysgalactiae, $\mathrm{E}^{+}$as environmental type including $S$. dysgalactiae, $\mathrm{C}^{+}$as contagious type including $S$. dysgalactiae.

*Significant value $(P<0.05)$. 
Morse et al. (1988). Further studies are needed to clarify the interaction of these parameters with the pathogen type on the occurrence of CM, when cows are exposed to heat stress.

The classes of AHL showed an increasing risk of contagious $\mathrm{CM}$ from low (AHL, $0.1<6.5$ ) to medium (AHL, $6.6<34.9$ ) values of AHL. On the other hand, higher AHL was not associated with significant CM outbreaks. The absence of a significant risk of $\mathrm{CM}$ for the higher class of AHL was unexpected and it seems in conflict with the risk identified for low and medium classes of AHL. This was a first attempt in defining class of risk for AHL in relation to $\mathrm{CM}$; therefore, other criteria must be verified in identifying the classes of AHL, as well as the presence of any confounding effects.

\section{CONCLUSIONS}

The heat loaded by cows during summer may represent a critical factor for animal health. Values of AHL greater than zero, which correspond to a climate condition for which cow has loaded heat in the day, was associated with a higher risk of CM. This approach has a bi-dimensional capacity and may measure the combination of intensity and length of exposure to critical heat thresholds. However, further research is needed to define the HLI thresholds and to identify the best lag times between exposure to heat and health outcomes in dairy cows. The achievements of these objectives could help to define better interventions to mitigate heat stress with positive effects on animal welfare and farm sustainability.

\section{ACKNOWLEDGMENTS}

The research was financially supported by the Italian Ministry of Agriculture within the Progetto LEO - sottomisura 16.2, PSRN (DM n. 18870/2017) and co-supported by MIUR (Ministry for Education, University and Research) initiative "Department of Excellence" (Law 232/2016). The authors gratefully acknowledge the Maccarese S.p.A Società Agricola (Maccarese, Roma) for providing cows' data and the Servizio Integrato Agrometeorologico della Regione Lazio (Roma) for providing weather data. The authors have not stated any conflicts of interest.

\section{REFERENCES}

Beniston, M., D. B. Stephenson, O. B. Christensen, C. A. T. Ferro, C. Frei, S. Goyette, K. Halsnaes, R. Holt, K. Jylhä, B. Koffi, J. Palutikof, R. Schöll, T. Semmler, and K. Woth. 2007. Future extreme events in European climate: An exploration of regional climate model projections. Clim. Change 81(S1):71-95. https://doi.org/10 $.1007 / \mathrm{s} 10584-006-9226-\mathrm{z}$.
Bernabucci, U., S. Biffani, L. Buggiotti, A. Vitali, N. Lacetera, and A. Nardone. 2014. The effects of heat stress in Italian Holstein dairy cattle. J. Dairy Sci. 97:471-486.

Bertocchi, L., A. Vitali, N. Lacetera, A. Nardone, G. Varisco, and U. Bernabucci. 2014. Seasonal variations in the composition of Holstein cow's milk and temperature-humidity index relationship. Animal 8:667-674. https://doi.org/10.1017/S1751731114000032.

Bouraoui, R., M. Lahmar, A. Majdoub, M. Djemali, and R. Belyea. 2002. The relationship of temperature-humidity index with milk production of dairy cows in a Mediterranean climate. Anim. Res. 51:479-491. https://doi.org/10.1051/animres:2002036.

Bucklin, R. A., L. W. Turner, D. K. Beede, D. R. Bray, R. W. Hemken, R. A. Bucklin, L. W. Turner, D. K. Beede, D. R. Bray, and R. W. Hemken. 1991. Methods to relieve heat stress for dairy cows in hot, humid climates. Appl. Eng. Agric. 7:241-247. https://doi.org/10 $.13031 / 2013.26218$

Condas, L. A. Z., J. De Buck, D. B. Nobrega, D. A. Carson, S. Naushad, S. De Vliegher, R. N. Zadoks, J. R. Middleton, S. Dufour, J. P. Kastelic, and H. W. Barkema. 2017. Prevalence of non-aureus staphylococci species causing intramammary infections in Canadian dairy herds. J. Dairy Sci. 100:5592-5612.

Das, R., L. Sailo, N. Verma, P. Bharti, J. Saikia, Imtiwati, and R. Kumar. 2016. Impact of 353 heat stress on health and performance of dairy animals: A review. Vet. World 9:260-268.

Ely, V. L., L. T. Gressler, J. F. Sutili, M. G. Ribeiro, M. M. da Costa, A. C. de Vargas, and S. de Avila Botton. 2019. Biofilm formation by Prototheca zopfii isolated from clinical and subclinical bovine mastitis in distinct growth conditions under different dyes. Cienc. Rural 49:e20180574. https://doi.org/10.1590/0103 $-8478 \mathrm{cr} 20180574$.

Flamenbaum, I., D. Wolfenson, M. Mamen, and A. Berman. 1986. Cooling dairy cattle by a combination of sprinkling and forced ventilation and its implementation in the shelter system. J. Dairy Sci. 69:3140-3147. https://doi.org/10.3168/jds.S0022-0302(86)80778 $-0$.

Fox, L. K., and J. M. Gay. 1993. Contagious mastitis. Vet. Clin. North Am. Food Anim. Pract. 9:475-487. https://doi.org/10.1016/S0749 $-0720(15) 30615-0$.

Gaughan, J. B., and J. C. Lees. 2010. Categorising heat load on dairy cows. Page 105 in 28th Biennial Conference of the Australian Society of Animal Production, 11-15 July 2010, Armidale, NSW Australia. Australian Society of Animal Production, Brisbane, Queensland, Australia.

Gaughan, J. B., T. L. Mader, S. M. Holt, and A. Lisle. 2008. A new heat load index for feedlot cattle. J. Anim. Sci. 86:226-234. https: //doi.org/10.2527/jas.2007-0305.

Gaughan, J. B., T. L. Mader, S. M. Holt, M. L. Sullivan, and G. L. Hahn. 2010. Assessing the heat tolerance of 17 beef cattle genotypes. Int. J. Biometeorol. 54:617-627. https://doi.org/10.1007/ s00484-009-0233-4.

Hahn, G. L. 1985. Management and Housing of Farm Animals in Hot Environments. Pages 151-174 in Stress Physiology in Livestock No. II. M. K. Yousef, ed. CRC Press Inc., Boca Raton, FL.

Hajat, S., R. S. Kovats, R. W. Atkinson, and A. Haines. 2002. Impact of hot temperatures on death in London: A time series approach. J. Epidemiol. Community Health 56:367-372. https://doi.org/10 .1136/jech.56.5.367.

Hogan, J. S., K. L. Smith, K. H. Hoblet, P. S. Schoenberger, D. A. Todhunter, W. D. Hueston, D. E. Pritchard, G. L. Bowman, L. E. Heider, B. L. Brockett, and H. R. Conrad. 1989. Field survey of clinical mastitis in low somatic cell count herds. J. Dairy Sci. 72:1547-1556. https://doi.org/10.3168/jds.S0022-0302(89)79266 $-3$.

IPCC. 2018. Summary for Policymakers. Global warming of $1.5^{\circ} \mathrm{C}$. An IPCC Special Report on the impacts of global warming of $1.5^{\circ} \mathrm{C}$ above pre-industrial levels and related global greenhouse gas emission pathways, in the context of strengthening the global response to the threat of climate change, sustainable development, and efforts to eradicate poverty. V. Masson-Delmotte, P. Zhai, H. O. Pörtner, D. Roberts, J. Skea, P. R. Shukla, A. Pirani, W. Moufouma-Okia, C. Péan, R. Pidcock, S. Connors, J. B. R. Mat- 
thews, Y. Chen, X. Zhou, M. I. Gomis, E. Lonnoy, T. Maycock, M. Tignor, and T. Waterfield, ed. World Meteorological Organization, Geneva, Switzerland.

Jaakkola, J. J. 2003. Case-crossover design in air pollution epidemiology. Eur. Respir. J. Suppl. 21(Supplement):81s-85s. https://doi .org $/ 10.1183 / 09031936.03 .00402703$.

Janes, H., L. Sheppard, and T. Lumley. 2005. Case-crossover analyses of air pollution exposure data: Referent selection strategies and their implications for bias. Epidemiology 16:717-726. https://doi .org/10.1097/01.ede.0000181315.18836.9d.

Lacetera, N., U. Bernabucci, D. Scalia, L. Basiricò, P. Morera, and A. Nardone. 2006. Heat stress elicits different responses in peripheral blood mononuclear cells from Brown Swiss and Holstein cows. J. Dairy Sci. 89:4606-4612. https://doi.org/10.3168/jds.S0022 -0302(06) 72510-3.

Lacetera, N., U. Bernabucci, D. Scalia, B. Ronchi, G. Kuzminsky, and A. Nardone. 2005. Lymphocyte functions in dairy cows in hot environment. Int. J. Biometeorol. 50:105-110. https://doi.org/10 .1007/s00484-005-0273-3.

Lecchi, C., N. Rota, A. Vitali, F. Ceciliani, and N. Lacetera. 2016. In vitro assessment of the effects of temperature on phagocytosis, reactive oxygen species production and apoptosis in bovine polymorphonuclear cells. Vet. Immunol. Immunopathol. 182:89-94. https:/ /doi.org/10.1016/j.vetimm.2016.10.007.

Lundberg, A., A. Nyman, H. E. Unnerstad, and K. P. Waller. 2014. Prevalence of bacterial genotypes and outcome of bovine clinical mastitis due to Streptococcus dysgalactiae and Streptococcus uberis. Acta Vet. Scand. 56:80. https://doi.org/10.1186/s13028-014-0080 -0 .

Maclure, M., and M. A. Mittleman. 2000. Should we use a case-crossover design? Annu. Rev. Public Health 21:193-221. https://doi .org/10.1146/annurev.publhealth.21.1.193.

Morse, D., M. A. De Lorenzo, J. Wilcox, R. J. Collier, R. P. Natzke, and D. R. Bray. 1988. Climatic effects on occurrence of clinical mastitis. J. Dairy Sci. 71:848-853. https://doi.org/10.3168/jds .S0022-0302(88)79626-5.

National Mastitis Council (NMC). 1999. Laboratory Handbook on Bovine Mastitis. NMC Inc., Madison, WI.

Nyman, A.-K., C. Fasth, and K. Persson Waller. 2017. Intramammary infections with different non-aureus staphylococci in dairy cows. J. Dairy Sci. 101:1403-1418.

Olde Riekerink, R. G., H. W. Barkema, and H. Stryhn. 2007. The effect of season on somatic cell count and the incidence of clinical mastitis. J. Dairy Sci. 90:1704-1715. https://doi.org/10.3168/jds 2006-567.

Pyörälä, S., and S. Taponen. 2009. Coagulase-negative staphylococciEmerging mastitis pathogens. Vet. Microbiol. 134:3-8. https://doi .org/10.1016/j.vetmic.2008.09.015.

Schütz, K. E., N. R. Cox, and C. B. Tucker. 2014. A field study of the behavioral and physiological effects of varying amounts of shade for lactating cows at pasture. J. Dairy Sci. 97:3599-3605. https:// doi.org/10.3168/jds.2013-7649.

Schütz, K. E., A. R. Rogers, N. R. Cox, and C. B. Tucker. 2009. Dairy cows prefer shade that offers greater protection against solar radiation in summer: Shade use, behaviour, and body temperature. Appl. Anim. Behav. Sci. 116:28-34. https://doi.org/10.1016/ j.applanim.2008.07.005.

Schütz, K. E., A. R. Rogers, Y. A. Poulouin, N. R. Cox, and C. B. Tucker. 2010. The amount of shade influences the behavior and physiology of dairy cattle. J. Dairy Sci. 93:125-133. https://doi .org/10.3168/jds.2009-2416.

Smith, D. L., T. Smith, B. J. Rude, and S. H. Ward. 2013. Short communication: Comparison of the effects of heat stress on milk and component yields and somatic cell score in Holstein and Jersey cows. J. Dairy Sci. 96:3028-3033. https://doi.org/10.3168/jds.2012 -5737 .

Smith, K. L., D. A. Todhunter, and P. S. Schoenberger. 1985. Environmental mastitis: Cause, prevalence, prevention. J. Dairy Sci. 68:1531-1553. https://doi.org/10.3168/jds.S0022-0302(85)80993 -0 .

Swartz, T., and C. S. Petersson-Wolfe. 2016. Pasteurella spp: A practical summary for controlling mastitis. Virginia Cooperative Extension. Accessed May 25, 2019. https://vtechworks.lib .vt.edu/bitstream/handle/10919/75563/DASC-67.pdf?sequence= 1Stevens/.

Tucker, C. B., A. R. Rogers, and K. E. Schütz. 2008. Effect of solar radiation on dairy cattle behaviour, use of shade and body temperature in a pasture-based system. Appl. Anim. Behav. Sci. 109:141-154. https://doi.org/10.1016/j.applanim.2007.03.015.

Valckenier, D., S. Piepers, A. De Visscher, and S. De Vliegher. 2019. The effect of intramammary infection in early lactation with nonaureus staphylococci in general and Staphylococcus chromogenes specifically on quarter milk somatic cell count and quarter milk yield. J. Dairy Sci. 103:768-782.

Vitali, A., A. Felici, S. Esposito, U. Bernabucci, L. Bertocchi, C. Maresca, A. Nardone, and N. Lacetera. 2015. The effect of heat waves on dairy cow mortality. J. Dairy Sci. 98:4572-4579. https://doi .org/10.3168/jds.2015-9331.

Wilson, L. A., G. G. Morgan, I. C. Hanigan, F. H. Johnston, H. AbuRayya, R. Broome, C. Gaskin, and B. Jalaludin. 2013. The impact of heat on mortality and morbidity in the Greater Metropolitan Sydney Region: A case crossover analysis. Environ. Health 12:98. https://doi.org/10.1186/1476-069X-12-98.

Zeinhom, M. M. A., R. L. Abdel Aziz, A. N. Mohammed, and U. Bernabucci. 2016. Impact of seasonal conditions on quality and pathogens content of milk in Friesian cows. Asian-Australas. J. Anim. Sci. 29:1207-1213. https://doi.org/10.5713/ajas.16.0143.

\section{ORCIDS}

A. Vitali $\odot$ https://orcid.org/0000-0002-4739-9077

A. M. Lees ำ https://orcid.org/0000-0003-4898-2843

U. Bernabucci @ https://orcid.org/0000-0002-8126-3042

J. B. Gaughan (ํ) https://orcid.org/0000-0001-5395-6901

A. Nardone ( https://orcid.org/0000-0003-1318-2125 